\title{
Pharmaceutical forms in Antidotarium Nicolai
}

\author{
Marta Pocuca $^{1 *}$, Dragan Stupar ${ }^{2}$ \\ ${ }^{1}$ Faculty of Medicine, University of Novi Sad, Hajduk Veljkova 3, Novi Sad, Serbia \\ ${ }^{2}$ Faculty of Pharmacy, Univrsity of Belgrade, Vojvode Stepe 450, Beograd, Serbia
}

Received November 2005, accepted June 2006,

\begin{abstract}
Pharmaceutical forms are equally important as pharmacodynamic effect of drug for expression of therapeutic effect. Antidotarium Nicolai was the first pharmacopoeia written in the beginning of the $12^{\text {th }}$ century by Nicolaus Salernitanus. Pharmaceutical forms were not described clearly in terms of type, structure, technological process and application. Salerno's pharmacotherapy, as it can be seen from the Antidotarium, was based on "sugar-honey pharmacy" and the only difference between pharmaceutical forms was viscosity of forms.

The following forms are described in the Antidotarium: electuaria, morsuli, pillules, trochisci, sirupi, emplastra, unguenta and olea.

Antidotarium Nicolai is of unique importance since it is the first attempt of systematisation of pharmaceutical forms. Although today's criteria differ significantly from Nicolaus's, this book still has a great value as it represents the basis for all further pharmacopoeias written many years after Antidotarium Nicolai.
\end{abstract}

Key words: pharmaceutical forms, Antidotarium Nicolai, electuaria, pillules, emplastra, unguenta

\section{Introduction}

Antidotarium Nicolai was the first pharmacopoeia written in the beginning of the $12^{\text {th }}$ century. The book was written by a medical school teacher in Salerno, Nicolaus Salernitanus. A popular legend says that Salerno Medical School was founded by four masters: Latin, Greek, Jewish and Arab (1). Historical evidence of the activity of the Salerno School of Medicine date back to the $10^{\text {th }}$ century, though the most productive period of the Salerno masters was between the $11^{\text {th }}-13^{\text {th }}$ centuries (2). The School was much respected already in 904, and its students were welcomed at the French royal castle (3). The students studied medicine and surgery for five years and practiced for one year under a supervision of an experienced physician (4). Salerno made contributions to medical knowledge until 1811, when it was closed by Napoleon (5).

Nicolaus was asked by his students to systematize the curriculum regarding preparation of the pharmaceutical forms. Nicolaus chose 142 prescriptions out of 1000, and

\footnotetext{
* e-mail: martapocuca@gmail,com

phone: +381 21472 0612; fax: +381 214720613
}

introduced regulations concerning the parts of medicinal herbs and quantities used. This made the curriculum clearer by far. He also introduced the new measurement system, which enabled preparation of small quantities of pharmaceutical forms. In Hilandar Medical Codex, the most famous reminded of Serbian medieval medicine science, from the beginning of the $16^{\text {th }}$ century, transcriptions from Antidotarium Nicolai (6) as well as from Antidotarium N. Praepositus (7) were clearly recognizable. Prescriptions from Antidotarium Nicolai were partly presented even in pharmacopoeias from the $17^{\text {th }}$ and $18^{\text {th }}$ century (8).

Nicolaus classified the pharmaceutical forms by alphabetical order of their names, so that one cannot define which of the pharmaceutical form is in question. The only exceptions are those wearing the form in their names, e.g. Pillulae aureae.

The Antidotarium Nicolai does not contain clear descriptions of the type and content of pharmaceutical forms, neither the procedure of preparation, or their application. The medicine marked as electuaria might be an unguentum, a suppository or a potion, so that all the efforts to systematize the remedies on the basis of pharmaceutical forms turned out to be unsuccessful. 
The form of a remedy is a term of newer date, and it describes the appearance of the medicine applied to a patient as well as the place and manner of application. As the medicines exist for ages, the pharmaceutical forms have been in use ever since, although under different names. Im the beginning, they were named "potion" or "dish", and their preparation and contents included different magic rituals.

The first written texts from the medicine domain, the old Babylon and old Egyptian readings from the $17^{\text {th }}$ to $7^{\text {th }}$ century BC point out to a variety of different medicines: potions, unguenta, cataplasms, bandages, tampons, clysters etc. These forms were also described in the early written forms of "Corpus Hippocraticum" ( $5^{\text {th }}-4^{\text {th }}$ century BC).

The Salerno pharmacotherapy, as can be concluded from Antidotarium Nicolai, was based on the "sugar-honey pharmacy", introducing the spirit of wine in pharmacy, and preserved until the $19^{\text {th }}$ century. If analyzed more thoroughly, the Antidotarium appears to be very monotonous. Apart from a few exceptions, all remedies are mixtures of drugs, honey or sirupus. The only difference among them, technologically, lies in the viscosity of certain medicines. However, this significant distinction cannot be determined, as there is no precise description of ingredients, and the viscosity of used honey or sirupus is not known.

\section{Discussion}

There are following pharmaceutical forms found in Antidotarium Nicolai: electuaria, morsuli, pillules, trochisci, srupi, emplastra, unguenta and olea. Some of these pharmaceutical forms have been preserved up to the present time.

Electuaria: The term electuaria comes from the Greek noun ekleikton, meaning "something to be licked". Regarding the application of this dgug, in "Corpus Hippocraticum" it is says: "The patient should lick the remedy along with honey". Such form of application is very rare and is hardly mentioned in the later Greek documents.

In the $13^{\text {th }}$ century, electuaria was defined in the following way: "Electuaria is named like that because it is prepared from elected (electis) drugs." In his work "Compendium Aromatariorum", Saladin from Ascolo explained that the term electuaria signifies "elected from diverse", as electuaria is prepared from many different ingredients. Such definition of electuaria became relevant in the period when electuaria started to be the best-known and most respected pharmaceutical form. They were permitted to wear a label "elected", while the licking remedies were already out of use.
Up to the $4^{\text {th }}$ and $5^{\text {th }}$ century, the electuaria distinctive features were: 1 . determined indication - lung diseases, 2. honey as vehiculum, and 3. the particular application method - "licking". In the following centuries, two features changed: the indication did not cover lungs and thorax diseases only, but is was indicated for almost all other diseases. The application method, after which the remedy got its name, also changed - electuaria could applied in all other application ways, except by licking.

The transformation (change of function) of electuaria occurred most probably in the $3^{\text {rd }}$ or $4^{\text {th }}$ century, when it was noticed that the fruits mixed with honey could be preserved for a longer period of time and be used in medical science. The use of electuaria was guaranteed once honey, and the whole mass, reached a certain "densitas", in Antidotarium Nicolai marked as "tehnicus viscocitas". Honey was taking over the role preservative, it corrected the taste of licking remedies and the medicinal substances were chosen to be applied in cases of all diseases. It seemed that the preparation was so simple, that neither Antidotarium, nor other medical documents paid too much attention to detailed preparation descriptions. However, electuaria is the pharmaceutical form most frequently prescribed to patients. In Antidotarium Nicolai, there are only 5 electuaria listed. According to the meaning of the pharmaceutical form, there are at least 75 electuaria out of 142 remedies. There are other proofs showing there were many more electuaria - prescription issued later that contained medicines sorted by diagnoses, indications or forms, and not by alphabet.

The difficulties in setting up criteria on electuaria preparation rise from the fact that there have been no detailed preparation descriptions, nor their clear definition. The additional obstacle lies in the impossibility to find out the contents of electuaria purely from its name. Although electuaria were the most frequently used medicines, they have remained mysterious. Approximately 5060 different drugs were named electuaria, which probably were not simply mixed with honey. It is known that with some other remedies, special attention is paid to the sequence of certain drugs. In the preface of Antidotarium Nicolai, it is emphasized that in the preparation phase of certain electuaria, the drugs should be grinded and sifted, while some other drugs should remain in bigger pieces, which is particularly important for electuaria used as a laxative. Instead of describing the preparation proces, the kind and origin of honey are described. In the preface, it is also emphasized that honey should not be too liquid, nor too hard, and that honey is the best preservative. Arnalds from Villanova gave a description of the honey viscosity test. Honey is proper- 
ly cooked and ready to use once one drop of it falls on the marble tile and does not spread. Saladin from Ascolo also paid special attention to honey. He described the quantity of drugs goes into $500 \mathrm{~g}$ of honey - each $500 \mathrm{~g}$ of honey is added to 2 ounces of drugs, and 3 ounces of drugs in laxatives in winter period. Finely, grinded drugs are added to electuaria, when removed from fire, so that the drugs would not lose its effect. These explanations are of newer date. In Salerno documents, there was no significant information on preparation of electuaria.

In Antidotarium Nicolai, electuaria have various consistencies, so that they can be grated, cut in small pieces and used as suppository, spread in the form of unguentum or swallowed as tablets. The issue here is not about the unique form of application - it is about the method of preservation.

The last electuaria, "electuaria theriacale" in DAB 6 become official in 1968, and in DAB 7 it was canceled as remedy.

Morsuli: The term morsuli is not used in Antidotarium Nicolai. There are, however, four remedies, deserving to wear that title. They is a special kind of electuaria, whose mass is so viscous, that it can be cut by knife. The same method of preparation is used for "Quittenkonfekt" quince dessert. Once a certain quantity of drugs is mixed with honey and cooked for some time, the mass is poured onto the marble tile and let cool down; it can be cut by knife in smaller pieces. Two stomahica remedies were prepared in such way, using sugar and rose water as vehiculum, instead of honey. The cooked mass used to be poured onto the marble tile, previously lubricated by rose oleum, and then it was made thinner. Once the mass turned cold, it was cut by a knife dipped in rose oleum. In the $17^{\text {th }}$ century, the form of sugar bonbons - confetti was very fashionable. Both pillules and morsuli are precursors of tablets. They differ from electuaria only in viscosity and appearance.

Pillules: Pillules used to signify a symbol in pharmacy. Prior to the invention of ttablets was invented in $20^{\text {th }}$ century, pillules presented a privileged form of a medicine. Later, the hormones chemistry pays a special attention to pillules. In the ancient medical documents, pillules were mentioned without any significance. The Babylon term kupatinnu, meaning "mixed, squeezed and rolled up" does not clearly describe the shape. The criteria defining a pillule are missing: the exact contents and dosage, as well as expiry date. These criteria are not important, as the prepared pillules used to be swallowed immediately. The drugs used to be rubbed with flour into pillules, and dipped into honey before swallowing.

Among several hundreds of Corpus Hippocraticum prescriptions, there are only a dozen for pillules. The term katapoton marked "all that is to be swallowed". Celsus adopted the Greek word catapotium and did not write much about preparation of pillules. He devoted his attention to their effects - he described painkiller pillules, sleeping pillules, anticoughing pillules, which were the size of peas or beans. Galen also hardly described pillules, but he mentioned them frequently. The doctors of Old Greece wrote about pillules quite frequently. There were prescriptions for pillules anti-diarrhea, the size of a berry. The drugs used to be chopped up, then mixed with honey and swallowed with warm water. However, there is neither weight nor number of ingredients mentioned in these prescriptions. There is no information on dosage or how long a patient should continue to take them. It is to be supposed that pillules were intended for immediate consumption.

The number of pillules to be prepared is often described as the quantity the patient should take in one day. One can only presume the dosage for longer period, based on the quantity of drugs and on the indicated size of the pillule (size of peas, drachma weight). The drugs were usually mixed with some viscous liquid (plant juices, honey) and out of the mass the pillules were made (facere, conficere). In several cases, pillules were taken sublingually. In some segments of these documents, the remedies having the same form as pillules are called trochisci. According to Antidotarium Nicolai, trochisci are not swallowed by a patient, but theywere used for preservation.

In Antidotarium Nicolai, the preparation of the first pillules is described, and all the others should have been prepared according to the given example. The preparation was quite simple: the drugs were mixed with a large quantity of vehiculum, so that the mass could be formed by hands. To prevent sticking of mass to hands, it was necessary to use oleum spread on hands before the process. The size, i.e. weight of a pillule was indicated. A pillule "sine quibus ess nolo" weighs 3 ounces, i.e. ca $75 \mathrm{~g}$. The pillules were the size of peas and out of such mass one could make $100-150$ pillules. There were 10 pillules per dose.

Some more detailed descriptions of pillules were written later on, containing also the indication of the expiry date.

Figure 1 shows the original instruction for the Pillulae auree preparation - Antidotarium Nicolai. 
Trochisci: Trochisci resemble pillules, but their background is quite complex, as the same term was used to denote several things. The early remedies that resemble trochisci are mentioned in Corpus Hippocraticum. These medicines were made of drugs, in the shape of a dense extract or a moist mass, formed into "pastille" and kept until consumption. The pastilles were not for internal use, but presented a method of preservation. Before use, they were supposed to be moistened and put on the sore point. Celsus gave the same explanation of his pastilles (quos trochiscos Graeci vocant). There were regulations for forming the drugs mass without fat that dries off, which can be dipped into vinegar or wine before use. It can be applied to different sore points as fatless cream. There was one exception from this Celsus concept - one regulation describes a pastille to be used internally, when a patient suffers from stone in the bladder. This recipe contains the weight of a pastille as well.

Celsus supposed that pastilles were called trochisci by Greeks. The Greek name was preserved to the newer date, whereas the Latin word pastillus is used today to mark the sucking tablets. Galen used the terms small circle or bun in his book about Theriak Andromachus, which is important for the definition of the term and history of trochisci, and contains three forms of pastilles: pastilles eyelashes, Scilla pastilles and Hedzchroon.

In Antidotarium Nicolai, there are 8 trochisci remedies. The "confection gallies muscatel" belongs to the same group, according to the form of trochisci. These remedies were actually a particular means for preservation, which should be mixed with drugs at certain moment and processed into confectiones magne. With gallie muscate "Que intrat in preciosissimis medicines et electuaris", the preparation was pretty clumsy. First, the trochisci of mastix, rubber and camphor were made with rose water, the mass was dried in shade, and then grated and mixed with drugs. The mass was then kneaded by hand and again trochisci were formed, with a concave part and clearly defined weight of 1.5 drachma. At the end, they were covered with musk deer and rose water.

Other trochisci that are precisely described are trochisci diarodon and trochisci de tyro, and they served probably as an integral part for preparation of other remedies. There are no recipes of other remedies that would reveal their preparation, nor description of indications. There is, however, information on trochisci anis, that helps overcome the water disease. The application of all trochisci is equal - the drugs were formed into trochisci by use of some liquid (wine or plant juice), dried in shade and kept before use. In fucco feniculi fcamonee bene trite \& puluerizate 3.vi. \&.5. admifceantur ita tantum $q$ puluts $\mathrm{fal}$ monee per pannum cum ipfo fucco fic expreffus. \& fit tanta fucci quantitas que fufficiat ad confe. ctıonem prlularum \& manibus primo inunctis oleo uiol.uel cómunt fécundum noftra doctriam: abluct, formentur in modum ciceris.

Pilule auree.

Filule auree pilule a rotonditate dicte duree ab excellétıa aur dicütur. ficut enım dutum inter cetera metilla preciof tus habetur: fic pilule ifte inter alas meliores approhantur. prupuele purk gant caput . lumen oculorum acuunt. tuciscofitate ftomaci \&i i teftinorum expellunt, \& fintmoleftro purgant medietas eft hbri.ii $\&$. $\frac{3}{3}$.it. It cucupe aloes diagridı añ.3.v.ro. apui feminis añ.3.ti. Q . . .amf

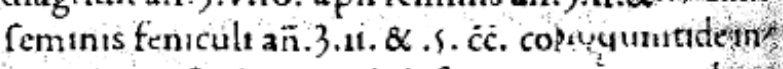
terioris mafticis añ.3.i. informentur in modeme ciceris cum aqua ifutionis dräg. dentur ' $2 n$ tero, ix. uel.xi.cum mulfa:aut cum uino. Pilule diacaftoree profunt paralifi:

Pllule diacaltoree a caltoreo dicte lút: $q$ upd intrat paralicic nirabiliter prolunt una uel tres diftcmperate cum aqua calida ndribus inciat? tta ur fuphus ipfe patiens iaceat iuxa ignem parts uum aliquantulum uertat $f e . \&$ ore apertofinat flegma exire. oculos mundificant. $\&$, dentes lap los $^{2}$

Fig. 1. Copy of the original instruction for the Pillulae auree preparation - Antidotarium Nicolai.

some recipes, the weight was marked in relation to drachma. There was no particular information on external use.

During the $19^{\text {th }}$ century, the term trochisci ceased to exist.

Sirupi: The preparation of sirupi, whose main ingredient is sugar, began after sugar started to be used in the Arabic medicine. A part of Sicily and South Italy are considered to be the first region where syrups were used. The term „sirupus“ comes from the Arabic word sarab, meaning a potion, a drink. In western medicine, the word „sirupus“ was used for the first time in medical documents in Salerno. It is not, however, clear, how the word was introduced in Latin.

Today, only Sirupus simplex has some significance in pharmaci. The same term was used in middle ages to describe a potion containing a mixture of drugs, the vehiculum consisting of sugar and water. The potion made only of sugar and water was unknown. 
In Antidotarium Nicolai, there are 10 sirupi and 2 sour sirupi. The first sirup mentioned is Sirupus rozaceus, described in details. Its use was supposed to serve as on example for preparation of all other sirups: boiling water is poured over fresh roses; the pot is covered with a lid, so that the fragrance would not evaporate. When the content gets cold, it should be squeezed and strained. This water is poured over fresh roses for several times, until it becomes red. Sugar is added - to the quantity of $2 \mathrm{l}$, is added $1 \mathrm{~kg}$ of sugar is begin, and then the mass is cooked to boiling, as the mass is being cooked, the sirupus gets very viscous at the end. In the middle ages, the process of cooking was accompanied by clearing (clarification), in the following way: the egg white is beaten and mixed with a little bit of cold water, and then added to the boiling sirup. Once the black foam appears on the surface, it is removed by spoon, and the new beaten egg is added. This is repeated, until the foam remains white, and the sirup becomes clear. Such process of clearing is described in all Salerno prescriptions, with certain variations. In one of the prescriptions, it is noted that sugar should be mixed with the egg white before it is put into rose water. The drugs were most frequently added in the following manner: then were into linen bags and soaked into hot sirup, so that the "power" of drugs would pass into the sirup. At the end, the sirup was put through rough and then fine filters.

It is important to mention that general remarks regarding sirup preparations quote the Rozen sirupus by Nicolaus, as the example. The sirupus is ready once the drop poured on the marble tile does not spread, or it remains hanging from the spoon, or is glued to one's nail. The same goal is achieved when the drop of sirupus drags or stretches between two fingers. In our understanding, this viscosity is imprecise and variable, depending only on the examiner and the manner of examination. However, it is important to note that, at sirupus preparation, examination and testing were required. The viscosity examination was significant for preservation, as sirup could be preserved only at certain concentration (density). It appears that the clearing processes were strict, but they had a big role - sugar kept the sirup usable. In those times, there was no refined sugar, but only the raw sugarcane one. Sugar used to be the substitute for honey. Both sugar and honey were to have equal medicinal effects, but sirups with honey were prepared as well. Such sirups were supposed to be cooked more of ten thanthose with sugar. This was described by Nicolaus regarding the Syrupus de papavere.

If vinegar was used instead of water, the sour honey was produced, oximel, and the viscosity was kept within the prescribed limits. The Oxi remedy is technically the most difficult one to be prepared in the whole Antidotarium. There are several different operations to be performed to produce the sour sirupus. The fresh drugs were also gradually prepared. The systematization of these remedies is complex, so that they could be called sour electuaria.

Emplastra: Emplastra, which are frequently bought in pharmacies today, are no longer produced in the old way, and differ a lot from the old "emplastra". The significant difference lies in their purpose - today's emplastra mostly offer mechanical protection, and not treatment of the sore point.

In Corpus Hippocraticum, one cannot find the term, but there are some mineral substances that contain fat, and are applied externally, by putting them onto the sore point.

According to the descriptions by Celsus, in the $1^{\text {st }}$ century, it was clear that the remedies contained resins, plant rubbers and lead, and oleum and wax were used as vehiculum. The preparation of emplastra was complex, as rubber or resin used to separate from vehiculum, and more than one operation was required.

In the $2^{\text {nd }}$ century, Galen gave emplastra a significant role. In his register "Medikamente nach den arte" (Medicines According to Type), six out of seven books were devoted to emplastra. Galen used the Greek word emplastera. In many cases, it is clear that emplastra are made of mineral substances, oleum or unguentum.

In Antidotarium Nicolai, the prescriptions show the extremely difficult mode of preparation of this form. For Emplastrum apostolocon, the resin should be dissolved in wine (soaked until it becomes swollen), and then cooked until the wine evaporated. The mass was added sawdust of lead-oxide and lithargium with plenty of oleum. It was heated until the mass became as solid as wax. Then wax was added, as well as drugs, and cooked until the mass became homogeneous. Then the mass was then put into cold water, and kneaded by hands, to squeeze the water out. Magdaleon is formed, by hands lubricated with oleum. It was preserved in such form. Although the prescription is clearly described, only people who know the basic rules of emplastrum preparation could make them.

There are only three emplastra in Antidotarium Nicolai. Compared to the other remedy forms, they were less frequently used.

Until the $20^{\text {th }}$ century, emplastra were described in books on medicines due to their chemical contents, i.e. salts of heavy metals and fat acids, along with the resins 
and oleum which were also ingredients of an emplastrum. Today, emplastra are attached to the sore points and indirectly help healing. Therefore, it is not the type of remedy as it was in the past, when lead was one of its ingredients.

Unguenta: In Greek medicine, there was no clear definition on differentiating unguenta from other remedies for external application. In Salerno region, unguentum was not precisely described too.

In Salerno period, there was a rule saying that unguentum consists of oleum, wax and drugs, but it was not described in Antidotarium Nicolai. There were also unguenta without oleum or wax, but there was no recipe for unguentum without fat. To prepare unguenta, one could encounter difficulties when adding drugs, wax and fat, as the remedy was supposed to be smooth. The use of wax is justified, considering the climate of Salerno region. The wax kept the unguenta firm and preserved for longer period.

Unguentum Citrinum was explained by words: "hoc modo fit": tragakanta was crumbled in a marble mortar by means of iron pestle. Other drugs were also crumbled in the same mortar, one by one, and then sifted through the fine linen sieve. The fat added was white pork fat, pork or goat lard, or chicken fat. The fat was heated in water bath, until it melted. It was then sifted through the linen sieve, and mixed with the drugs powder, except for camphor and borax. The mass should be stirred carefully, until it became homogeneous. It was then poured into a pot made of lemon wood, heated and stirred in water bath. When the water started boiling, the mass should be poured into another pot. Camphor and borax were added. The mass should be stirred until it grew cold. At the end of the recipe, there was a remark: "Remember to add 8 times $500 \mathrm{~g}$ for $500 \mathrm{~g}$ of drugs".

One of the oldest unguenta in Antidotarium Nicolai is Unguentum marciaton. This unguentum was also quite complex for preparation. Some of the plants listed were supposed to be collected in particular days in May, between 3 and 12 o'clock. The crumbled plants were put to soak in the best wine, for seven days. On the $8^{\text {th }}$ day, the mass was heated, until the wine evaporated. Oleum was added and then the mass was cooked, until it significantly decreased in size. The mass was filtered carefully. The filtered oleum was cooked again, and resin (styrax) was added. When the mass was simmering, some butter or fat was added, then drugs and afterwards narden oleum, mastix and thyme, and wax at the end. Once the wax was melted and dissolved, the mass was removed from the fire and stirred until cool. The cold and dense remedy was kept in small pots.
There is a description for an emulsion, i.e. unguentum containing some water - "Pappell" unguentum. The drugs used to be macerated in oleum for 20 days, then crumbled and formed with fat into a magdaleon, which could be formed on not before 20 days later. Very often, the drugs were macerated in wine, which was later on cooked. There is also a description of a water extract remedy: $500 \mathrm{~g}$ of the remedy should be mixed with 2 times $500 \mathrm{~g}$ of oleum, and cooked until the juice on the surface evaporates.

In Unguentum Laxativum, some type of emulsifier was required. Before the preparation, juice and oleum were cooked, and when the mass was ready, wax and gall of a bull were added.

The first emulsion was Unguentum alburu, and oleum and rose water were the basis for the emulsion.

In Antidotarium, each unguentum was prepared according to a special recipe, and there were no general rules. The only conclusion about unguenta is that each remedy named unguentum contained fat and was applied externally.

The majority of unguenta contains the mixture of fat, oleum and wax, as a base. At the end, it is to be noted that electuaria (remedies for system use) were occasionally used as unguenta.

Unguenta and emplastra belong to the pharmaceutical forms whose application is described very precisely. For each of the unguenta, there is a thorough instruction on its application. Very often, there are several processes of preparation listed, but recipes differ among themselves.

Olea: When talking about olea, it becomes clear that there is a thin borderline between the two usages - the one in science/treatment, and the domestic one. Many olea are used daily as food products. The medicinal oleum, as a remedy, will be discussed hereafter.

In Hypocratic medicine, there were many types of olea and oily mixtures in use. There were a few recipes for preparations of olea, and terminology varied, so that there was no clear picture on these remedies.

In Latin, there are two different terms: unguentum and oleum. It seems that Celsus did not pay special attention to olea, whereas Marcellus Empiricus named many olea, originating from different drugs.

The Greeks used to call the remedies myra, and in Salerno literature they used to be called oleum. Whatever 
their name was, several types of olea were soon distinguished. Compendium Magister Salernus, which was written at the same time as Antidotarium Nicolai, contains several chapters on olea. It has been established that the production of oleum from dried drugs differs from that produced from the green plants. The dried drugs are cooked in oleum and then filtered. The fresh drugs are poured in a pot, along with the oleum. The pot is put into another pot with water. The pot with water is heated, paying attention that the water does not come into the pot with drugs and oleum. Magister also lists the mixed oleum, called Oleum laxativum, according to its indication. It is important to mention that the text describes the first destillation of ethereal oleum. It is a very simple preparation of Oleum Juniperi.

Olea listed in Antidotarium Nicolai can be classified in two groups: olea produced from only one drug (there are five olea of this kind: Olea rosatum, sambucinum, violaceum myrtinum and commomellinum) and the complex medicinal olea (they are Oleum mandragoratum and Oleum frigidissimum).

The preparation method for the first group of olea is described with Oleum rosatum. One liter of clear olive oleum was mixed with $750 \mathrm{~g}$ of roses, torn apart a little bit. The pot with such mixture was put into water bath. It was cooked until two thirds of the whole quantity evaporates.

Oleum camomellinum was prepared in a slightly different way. $250 \mathrm{~g}$ of chamomile picked in July was put into a glass jar with oleum. The jar was exposed to sun, tightly closed. Forty days later, the oleum was ready for use.

Oleum mandragoratum required drugs with strong effect: mandrake juice, henbane juice, poppy cocoon juice and pomegranate juice. All juices were poured into oleum, exposed to sun for 10 days and occasionally stirred thoroughly. On the $11^{\text {th }}$ day, the mixture was cooked until all the juices were boiled. The mass was then removed from fire and cooled. At the end, other drugs were added, e.g. opium. The last sentence of the monograph gives this oleum a different name - unguentum.

Oleum frigidissimum (cooled) consisted, besides others, from very strong drugs, which were cooked with oleum, until the juice vanished. After cooling, it was necessary to wait until the drugs settle, and only the light fluid of supernatant was to be used.

\section{Conclusion}

For a remedy to demonstrate its therapeutic effect, both its pharmaceutical form and the pharmacodynamic actions are equally important.

Out of all pharmaceutical forms described in Antidotarium Nicolai, the following are not in use any longer: electuaria, morsuli and trochisci. These forms are particular for their various methods of application. Today, each pharmaceutical form is used in one determined way only. The consistency of electuaria allows them to be grinded, cut in small pieces, to be used as suppository, spread as unguentum or swallowed as a pillule. In essence, it is not the unique form of the remedy to be applied in one way only, but the method of preservation. Morsuli, is a special form of electuaria, whose mass is so viscous that it can be modeled and cut by knife. Trochisci resemble pillules, but the term designates a form of preservation, and not a shape of a medicine.

Other pharmaceutical forms presented in Antidotarium Nicolai, except for electuaria, morsuli and trochisci, have been in use up to date.

Antidotarium Nicolai is a unique book, being the first effort to systematize the pharmaceutical forms. Although the modern criteria for systematization differ greatly from Nicolaus's, the book is of priceless value and presents the basis for all other pharmacopeias written many years after Antidotarium Nicolai.

\section{References}

1. L. Glesinger, Povijest medicine, Š kolska knjiga, Zagreb 1978, pp 95-102

2. M. Pasca, The Salerno School of Medicine, Am J Nephrol, 1994, 14 (4-6), pp 478-482

3. A.S. Lyons and R. J. Petrucelli Medicine, An Illustrated History, Harry N. Abrams, New York, 1978, pp 319-321

4. H. Tartalja, Pravila Salernske medicinske škole, Saopstenja PLIVA, pp 119-126

5. M.T. Southgate, Salerno-Something Old, Something New, JAMA, June 19 1967, Vol 200, No 12, pp

6. R. KatiC, Uvodna studija, Hilandarski medicinski kodeks N.517, Narodna biblioteka Srbije, Beograd 1989, pp 503

7. J. Maksimovic, Farmakoloski spisi stare srpske medicine, Pharmaca Iugoslavica 33, 1995, pp 55-58

8. D. Goltz, Mittelalterliche Pharmazie und Medizin, Dargestellt an Geschichte und Inhalt des Antidotarium Nicolai, Wissenshcaftlishe Verlagsgeselschaft MBH, Stuttgart, 1976 


\title{
Резиме \\ Фармацевтско дозирани форми во Antidotarium Nicolai
}

\author{
Марта Почуча ${ }^{1 *}$, Драган Ступар² \\ ${ }_{1}^{1}$ Меяицински факулиеети, Универзитетет во Нови Са9, Хаяук Вељкова 3, Нови Са9, Србија

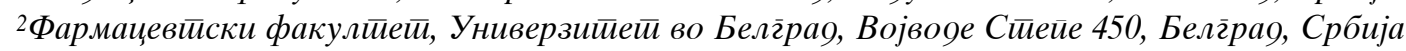

Фармацевтско дозираните форми имаат подеднакво значење како и фармакодинамскиот ефект на лекот за постигнување на бараната терапевтска ефикасност. Antidotarium Nicolai е првата фармакопеја, напишана на почетокот на XII век од страна на Nicolaus Salernitanus. Во истата, фармацевтско дозираните форми не се јасно раздвоени по однос на видот, структурата, технолошкиот процес и апликацијата. Салерновата фармакотерапија се базирала на т.н. "шеќер-мед фармација" и единствена разлика меѓу фармацевтско дозираните форми била вискозноста на препаратот.

Bo Antidotarium Nicolai се опишани следниве фармацевтски форми: electiaria, morsuli, pillules, sirupi, emplastra, unguenta и olea. Иако денешните критериуми значително се разликуваат од оние опишани во Antidotarium Nicolai, оваа книга е од огромно значење бидејќ́ претставува основа на сите други фармакопеи напишани многу години подоцна по Antidotarium Nicolai. 